\title{
The Bioprocessing Quick Wins from Avocado Fruit in Uganda
}

\author{
Emmanuel Baidhe, Nicholas Kiggundu, Noble Banadda \\ Department of Agricultural and Biosystems Engineering, Makerere University, Kampala, Uganda \\ Email: ebaidhe@gmail.com, kiggundu@caes.mak.ac.ug,banadda@caes.mak.ac.ug
}

How to cite this paper: Baidhe, E., Kiggundu, N. and Banadda, N. (2020) The Bioprocessing Quick Wins from Avocado Fruit in Uganda. Advances in Bioscience and Biotechnology, 11, 405-419. https://doi.org/10.4236/abb.2020.118028

Received: July 8, 2020

Accepted: August 25, 2020

Published: August 28, 2020

Copyright (อ 2020 by author(s) and Scientific Research Publishing Inc. This work is licensed under the Creative Commons Attribution International License (CC BY 4.0).

http://creativecommons.org/licenses/by/4.0/ (c) (i) Open Access

\begin{abstract}
Bioprocessing can help redeem the economic value for avocado (Persea americana) in Uganda. This study reviews the virgin potential of avocado bioprocessing in Uganda. Avocado consists of flesh, seed, and peel. The review indicates that the waste seed and peel are vital for development of high-value products. Both the edible part and waste (peel and seed) can be used for biogas production through a solid-state fermentation process. Biodiesel can be developed using avocado seed oil through a process called transesterification. Avocado oil is a better alternative for biodiesel production compared to waste cooking oil as it requires no further conversions processes for transforming fatty acids to esters. The starch-rich avocado seed is a suitable substrate for bioethanol, pigment and starch production. The high starch content places the avocado fruit as a potential: 1) raw material for the production of bioplastics; 2) substrate for bacterial culture media production as opposed to potatoes, cereals, and cassava that double as a staple food. Avocado seeds can also be used for the production of antioxidants relevant for preventing enzymatic browning, thereby increasing product shelf life. Despite the quick wins, there is a need for increased research, financing, personnel training and development of appropriate policies to spur the benefits and untapped potential of avocado bioprocessing in Uganda. The circular economy of avocado waste alone into high-value products could increase gains in the environment and stimulate industrial development, especially the cosmetic, food and pharmaceutical industries in Uganda.
\end{abstract}

\section{Keywords}

Avocado, Bioprocessing, High-Value Products, Industrial Development, Uganda

\section{Introduction}

Avocado (Persea americana) is a berrylike fruit containing a single seed origi- 
nating from Mexico and Central America [1] [2] [3]. Avocado grows under different climatic conditions and management practices [4], which favours its production worldwide. In 2017, the world avocado production was about 5.92 million MT [5]. North and Central America contributes the greatest share of the produce with about $70.3 \%$, followed by Africa and Asia at $15.2 \%$ and $10.9 \%$ respectively [6]. In East Africa (EA), Avocado production has greatly increased from 245,063 to 384,759 Tons between 2005 and 2017 [7]. Figure 1 shows that the amount of avocado production in EA relates directly to the area harvested. This could be attributed to the favoring climatic and soil conditions in EA.

Avocado locally known as Ovakedo is found in almost all parts of Uganda [8]. This is attributed to its ability to thrive in varying altitude and climatic conditions. The crop does well in altitudes ranging from 1400 to $1600 \mathrm{~m}$ above sea level [8]. According to [9], most avocado production in Uganda is done in the districts of Mpigi, Masaka, Kampala, Mukono, Iganga, Tororo and Mubende. According to [8], Jumbo and Hass are the most grown avocado varieties in Uganda. Avocado is rich in both nutritional and medicinal components [10] [11]. Without considering banana, the avocado nutritional value is assumed to be four times that of other fruits [12]. This partially explains the increasing production and consumption rates.

The avocado fruit consists of three parts that is flesh, seed, and peel (Figure 2). In Uganda, avocado flesh is the most used of the entire fruit. It is consumed as a food salad. The seed and peel are either utilized as animal feed or discarded to the garden where it ferments to add manure to the soil. Notwithstanding, the numerous documented health and nutrition benefits, avocado value addition and bioprocessing in Uganda are still poor [13]. Through bioprocessing, several high-value avocado products can be developed. Bioprocessing involves the use of living cells or their constituent components to develop not only desired but high-value products [14] [15]. High-value avocado products have the potential to reach consumers across the age divide. This paper seeks to provide a review of the potential for avocado fruit bioprocessing in Uganda, together with the opportunities and limiting factors for the development of the industry.

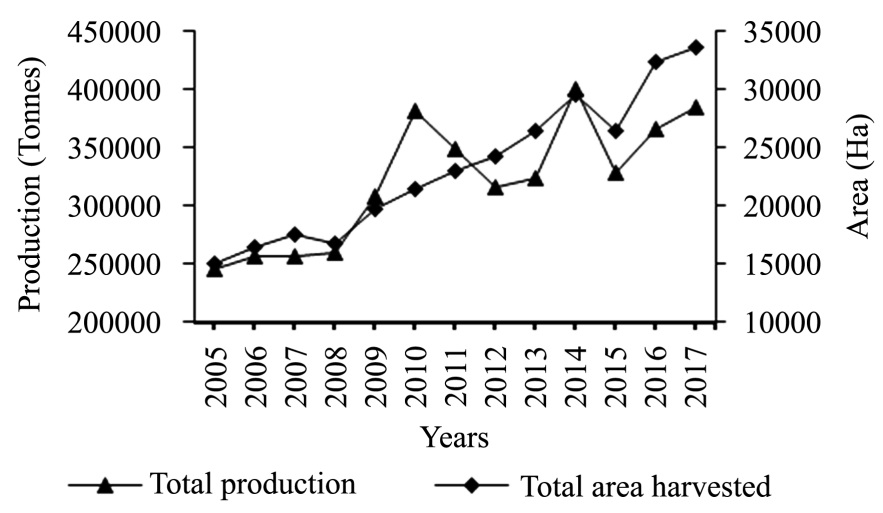

Figure 1. Total avocado production and area harvested for East Africa region from 2005 to 2017 [7]. 


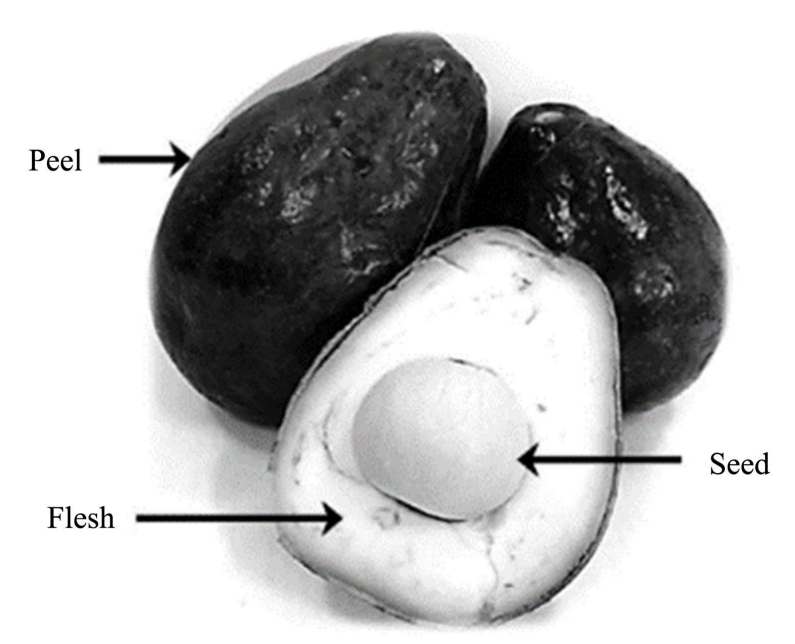

Figure 2. Avocado fruit [16].

\section{Nutritional and Physiochemical Composition of Avocado Fruit}

The avocado fruit consists of significant amounts of essential nutrients for human consumption. According to [17], one-half of avocado is composed of dietary fiber (4.6 g), total sugar (0.2 g), potassium (345 mg), sodium (5.5 mg), magnesium (19.5 mg), vitamin A (5.0 $\mu \mathrm{g}$ RAE), vitamin C (6.0 mg), vitamin E $(1.3 \mathrm{mg})$, vitamin $\mathrm{K} 1(14 \mu \mathrm{g})$, folate $(60 \mathrm{mg})$, vitamin B6 $(0.2 \mathrm{mg})$, niacin $(1.3$ $\mathrm{mg})$, pantothenic acid $(1.0 \mathrm{mg})$, riboflavin $(0.1 \mathrm{mg})$, choline $(10 \mathrm{mg})$, lutein/zeaxanthin $(185 \mu \mathrm{g})$, cryptoxanthin $(18.5 \mu \mathrm{g})$, phytosterols $(57 \mathrm{mg})$, and high-monounsaturated fatty acids $(6.7 \mathrm{~g})$ and $114 \mathrm{kcals}$ or $1.7 \mathrm{kcal} / \mathrm{g}$ (after adjusting for insoluble dietary fiber). These can have a wide range of health benefits. The folate, vitamin C, riboflavin, and vitamin B6 are all essential in iron absorption, red blood cell formation, and/or hemoglobin function. According to [18], of the infants on contemporary feeding, over $45 \%$ exceed the recommended sodium intake while only $5 \%$ meet the recommended dietary potassium intake. The introduction of avocado into infant diets may improve the situation as it has less sodium yet rich in potassium. The phytosterols in avocado present great anti-inflammatory properties. Vitamin $\mathrm{C}$ and vitamin $\mathrm{E}$ in avocados help in skin nourishment. The monounsaturated fats help reduce blood cholesterol levels and decrease the risk of heart disease.

\section{The Potential of Avocado Fruit Bioprocessing in Uganda}

\subsection{Avocado for Production of Bioenergy}

Energy is a major driver for most human activities [19]. It is derived from both renewable and non-renewable sources. Whereas non-renewable energy sources may be more energy-dense, they contribute to environmental pollution [20]. The use of renewable sources such as bio-waste becomes handy [21] [22]. Avocado has great potential for bio-energy production. Avocado can be used for the production of biogas [21], bioethanol [23] and biodiesel [24]. 


\subsubsection{Biogas Generation}

Access to electricity in Uganda stands at about $20.4 \%$ nationwide and $10 \%$ in the rural areas for all energy forms [25]. Biogas generation can improve the energy coverage in Uganda for most homes especially for cooking and lighting in areas without the electric grid. Replacing firewood with biogas for cooking consequently reduces pressure on the forest cover. The forest cover in Uganda has been greatly invaded for both firewood and charcoal making, energies that contribute close to $95 \%$ of the total primary domestic energy consumption [26]. Biogas use also saves women and children that are often charged with the cooking role from the dangers of continuous exposure to smoke [27]. The use of biogas for lighting helps improve the living conditions as it reduces human exposure to carcinogenic fumes that result from combustion of paraffin candles [28].

Biogas is generated by solid-state fermentation of both the edible part and the waste parts such as seed and the skin. In addition to energy, the anaerobic digestion of avocado generates organic residue used as organic fertilizer [19] [29]. Whereas avocado is used as food, the use of avocado waste for energy production reduces the impact of avocado bioprocessing on food security [30]. The avocado seed represents about $16 \%$ of the total fruit [6] [31]-[36]. However, it is one of the under-utilized parts of the fruit [10]. Assessment of the energy potential of the avocado seed by Perea-Moreno et al. [6] shows that avocado stone has a higher High Heating Value (HHV) making it a viable source of energy. Reference [22] reports that avocado seed reached its ultimate biogas potential earlier than banana and potato peels. Avocado peels can work as substrates for biogas production. The use of by-products will also reduce their negative effect on the environment in Uganda [2] [37] [38].

\subsubsection{Biodiesel Generation}

Biodiesel can be produced using avocado oil through a process called transesterification [24]. Biodiesel has been found to have a better advantage over petroleum diesel because of its low carbon monoxide emission [24]. Also, carbon dioxide generated through the combustion of biodiesel is recycled through photosynthesis thus reducing the greenhouse effect [24] [39]. Biodiesel reduces particulate matter emissions by over $75 \%$ [40]. Biodiesel is mainly produced using waste cooking oil. However, waste cooking oil has different properties that affect biodiesel quality [41]. Therefore, the use of non-edible vegetable and animal fats and oils has become popular. The avocado seed oil contains free fatty acid less than $2 \%$ thus requiring no further conversion processes for transforming fatty acids to esters [39].

\subsubsection{Bioethanol Generation}

Bioethanol is ethanol derived from biological sources, especially simple sugar and cellulose. Using a catalyst and an enzyme, polysaccharides are hydrolyzed into glucose by heating. The glucose is then fermented to produce ethanol [42]. The use of bioethanol is on the rise mainly because of environmental concerns related to fossil fuels and the depleting fossil reserves [43]. The avocado seed is 
rich in starch with about 30\% (wet basis) of its total composition [31]. This makes hydrolysis and consequently fermentation possible with avocado seeds. Bioethanol is an important ingredient for the development of household and personal products such as cosmetic and beauty products, hair sprays, and lotions [44] [45]. Much as the use of ethanol from liquor industries in cosmetics is controversial to the Islamic denomination, the use of bioethanol derived through natural fermentation promotes market acceptance among the Islamic community [45] [46]. Bioethanol also contributes to the fuel industry. Bioethanol is used in transport as an octane increaser since it has a higher octane number of 108 than gasoline at 88 [47]. Also to note, as the entire world is grabbling with the deadly corona virus (SARS-CoV-2), alcohol-based sanitizers have been widely promoted in Uganda as strategy for controlling the spread of the COVID19 disease. Bioethanol from avocado can contribute to the development of these sanitizers thus improving the market value for avocado. The World Health Organization listed ethanol at $80 \%(\mathrm{v} / \mathrm{v})$ as an essential medicine [48]. Avocado-based bioethanol can be further used for production of methylated spirits. Methylated spirit is about $90 \%$ by volume alcohol [49]. Methylated spirit also called denatured ethanol can be used as a preserving solvent in the production of cosmetic products, perfumes and vanishes. Methylated spirit is used to clean and disinfect wounds to prevent bacterial growth. There is a wide market for methylated spirit in Uganda ranging from community health units, institutional health centers, hospitals, as well as hair salons.

\subsection{Avocado for Production of Pigments}

Pigments have been instrumental in Uganda especially in the making of mats, ropes, home-based craft material as well as industrial leather production [50]. Both natural and synthetic dyes have been used. However, natural dyes are gaining an advantage over synthetic dyes since they are less-toxic, non-carcinogenic and biodegradable [50] [51] [52]. There is a growing need for eco-friendly, and less toxic coloring solutions [51]. Currently, consumers are willing to pay a relatively higher price for eco-friendly products as a way of protecting nature [53]. This makes the use of avocado for pigment production more viable. Many studies have emphasized avocado seed as a raw material for pigment production [36]. The greatest percentage of pigments is extracted together with the oil. Nonetheless, many other pigments remain un-utilized as they exist in the flesh and skin of avocado [54].

\subsection{Avocado for Production of Starch}

Starch in Uganda is mainly imported. Starch is used in both the food as it provides desirable texture and consistency to food [31] [36] [55] and the pharmaceutical industry as an excipient [56], a tablet and capsule binder, diluent, and as a disintegrant [55]. For years, corn, potato, cassava, and rice grains have been used for starch production. However, the high demand for starch for different industrial applications poses a food security issue. Reference [57] notes the need 
to investigate alternative sources of starch. The avocado seed has been found to contain about 30\% (wet basis) [31] and 75\% (dry basis) starch content [35] [36] [58] depending on the cultivar. Avocado seed, therefore, has the potential for starch production [34] [35]. Starch from avocado can contribute to the manufacture of paper, adhesives and biodegradable packaging material for different food items [31] as well as the textile industry [57]. Some of the biodegradable packing items that can be developed include disposable cups and plates. These bio-based packaging materials may offer a possible alternative to traditional synthetic packaging materials, thereby reducing the environmental impacts relating to packaging material usage [59].

\subsection{Avocado for Production of Anti-0xidants}

The fruit processing industry is on steady growth in Uganda. Fruits processed in Uganda such as bananas, potatoes, Irish potatoes, mangoes, pineapple are susceptible to enzymatic browning. Enzymatic browning is regarded as the second largest cause of food deterioration after induced microbial contamination [60]. Browning leads to loss of flavor, odor, and nutritional value for the fruits [61]. Some of the methods employed include heat treatment (blanching), conservation using a modified atmosphere and dipping in anti-browning agents [60] [61]. Whereas blanching is the most common and effective method, it alters the flavor and nutrient value for the food product. Therefore, the use of organic anti-browning agents could significantly improve the food industry. Avocado stones have high polyphenol content with antioxidant and antimicrobial power [32] [62] [63] [64]. Anti-oxidants are very useful in food preservation to increase shelf life and prevent enzymatic browning.

\subsection{Avocado for Production of Bacterial Culture Medium}

Culture media is used for the growth and identification of microorganisms. Culture media serves as a source of carbon, nitrogen, energy, Sulphur, phosphorus, and minerals for the growth of microorganisms [65]. Commercially available culture media are expensive and sometimes unavailable especially in developing economies [65] [66]. These high costs for bacterial culture media have triggered extensive research in the development of alternative culture media using locally available and affordable raw material [67]. Therefore, the use of bio-products as culture media is gaining special attention [66]. Plant material and their derivatives contain numerous nutrients like sugars, amino acids, vitamins and minerals relevant for microbial growth and fermentation [68]. The high starch content (75\% dry basis) [34] for the waste avocado seed better places the avocado fruit as a potential substrate for bacterial culture media production as opposed to potatoes, cereals, and cassava that double as food material.

\section{Opportunities for the Development of Avocado Bioprocessing in Uganda}

Avocado bioprocessing in Uganda could be at such a critical point for its devel- 
opment given the following reasons:

\subsection{Inclusion of Bioprocess Engineering in Makerere University Curriculum}

Whereas bioprocessing is not well developed in Uganda, there is hope after the introduction of bioprocessing engineering in the Makerere University curriculum [69]. The program saw its pioneer students in the August 2019 intake. The bioprocess engineering program will prepare students to engage in the emerging bioprocessing and biofuels industry to develop energy and related chemical products from renewable and biodegradable resources. This will be achieved through hands-on practical and internship opportunities during study at the university. Therefore, the program will pave the way for the development of the bioprocessing workforce in Uganda. The fruit processing industry is on steady growth in Uganda.

\subsection{Uganda Vision 2040}

Uganda Vision 2040 envisages leap-frogging Uganda from a predominant low-income to a competitive middle-income economy. Development of agriculture is one of the strategies emphasized to bring the blueprint to light. The vision focuses on agricultural value-addition as a strategy for increasing the market value for the different agro-products [70]. This explains the commitment of the Government of Uganda to support agriculture and the subsidiary sectors. Also, the adoption of bioprocessing will contribute to the development of high-value products from avocado to support various industries which eventually creates employment for the population.

\subsection{Increased Awareness of Environmental Conservation}

The increasing effect of global warming has caused great alarm. Uganda just like sister countries has joined the force in reducing the after-effect of climate change. The use of biological processes that are eco-friendly, and require organic substrates that are easily replenished has been widely promoted. The use of bioplastics developed using starch from avocado, biofertilizer generated as slurry from biogas production, bioenergy can significantly contribute to environmental sustainability in Uganda. They will reduce the dependence of wood, which is currently the most widely used energy source in the rural areas in Uganda [71] [72], the use of synthetic fertilizers that have long-lasting effects on the environment.

\section{Limitations of Avocado Bioprocessing in Uganda}

Avocado bioprocessing in Uganda remains insignificant even with well-documented health and nutrition benefits. The major hindrances to the development include:

\subsection{Limited Awareness among Farmers and Producers}

The majority of the farmers and avocado dealers have no idea what potential is 
possessed in the avocado fruit. Avocado bioprocessing is not an avenue that has been well surveyed to understand its potential contribution to Uganda's economy. The excess and relatively less palatable avocado are often wasted due to limited information on how well they can be utilized for oil extraction and energy production among others.

\subsection{Inadequate Trained Personnel}

Bioprocessing is such a critical process dependent on environmental conditions such as substrate concentration, enzymes, $\mathrm{pH}$, and temperature [73] [74] [75]. It is therefore important that the person undertaking a bioprocess be trained enough to manage the different conditions at optimal levels [73]. Uganda at the glance does not have enough trained personnel for bioprocessing. Sister professions such as chemical engineering, food technology, biotechnology offered at Makerere University and Kyambogo University have passed out several graduates. However, these have sought opportunities in other branches of science as opposed to bioprocessing.

\subsection{Limited Financial Capacity for Farmers}

Production of high-value products requires high-tech machines that are mainly imported from developed countries. These carry high transport costs thereby becoming expensive for the small-scale farmer. Financial institutions also offer loans at very high-interest rates under stringent conditions. Therefore, many processors are unable to access a financial boost for their production. Several financial institutions in Uganda have subsidized the lending rate on agricultural loans, but farmer adoption is still low. This may be attributed to the lack of collateral security for the loans [76]. Just like for other agricultural produce, limited agricultural financing is responsible for the slow expansion of avocado bioprocessing.

\subsection{Limited Research on Bioprocessing}

There is no research published on the potential of avocado bioprocessing in Uganda, an indication for limited research. Avocado bioprocessing like other related technologies requires extensive research if complex systems are to be remodeled to appropriate technologies (AT) usable in developing countries like Uganda. Appropriate technologies must fit small-scale production, easy to use and repair, and are relatively less expensive [77]. This relates to the low adoption of the technology thus withholding the enormous benefits of avocado bioprocessing.

\subsection{Lack of Guiding Policies}

Uganda currently has no policy to harmonize the biotechnology industry. Bioprocessing is a discipline that contributes to the benefits of biotechnology. In 2012, the National Biotechnology and Biosafety Bill was drafted and sent to par- 
liament for discussion. The Bill was developed to ensure the safe development and use of modern biotechnology. The Bill was later renamed Genetic Engineering Regulatory Bill 2018 and passed by the Parliament of Uganda. Unfortunately, the Bill was rejected by the President of the Republic of Uganda sighting inconsistencies. The President sought redress from the Parliament before it's assented into law. Therefore, the country remains with no proper framework against which different bioprocessing and its subsequent products can be assessed for public acceptability.

\section{Future Research Prospects}

The study has provided insights into the use of avocado bioprocessing for the transformation of the economy in Uganda. Whereas several studies evidence that avocado has the potential for the development of the cosmetic, food, pharmaceutical industry, future research can further accelerate the process. We suggest the following ideas to inform future research though not listed in the order of priority:

- Development of appropriate technologies suitable for the exploitation of the potential of avocado bioprocessing in Uganda

- Assessment of the nutrient and phytochemical compositions for the different avocado varieties grown in Uganda. This will inform which varieties are best suited for the various bioprocesses in Uganda, therefore informing production scalability.

- Quantification of the avocado waste in Uganda and assessing its potential for bioenergy production as an environmental protection strategy

\section{Conclusion}

This study reviewed the potential of avocado bioprocessing in Uganda. It was found that the avocado seed and peel have an inexhaustive potential for the production of products such as biogas, biodiesel, and bioethanol, pigments, starch, antioxidants, and bacterial culture media. There is however need for increased research, financing, personnel training, and development of guiding policies to propel the avocado bioprocessing industry in Uganda. The use of bioenergy reduces the level of greenhouse emissions thus contributing to environmental conservation. Biogas can substantially reduce dependence on forest biomass, thus reducing health risks associated with firewood. Avocado-based bioethanol and its constituent products such as methylated spirit are critical solvents in production of cosmetics, lotions, varnishes as well as antiseptics and sanitizers, yet widely accepted as opposed to the industrial ethanol. Avocado-based pigments can propel the tourism industry through development of various crafts such as mats, ropes, and leather items. Starch and antioxidants are vital in the development of medicinal and food products. The use of avocado waste will not only generate high-value products but also help recover its economic value to help the country realize the Uganda Vision 2040 through agriculture. Avocado 
bioprocessing will contribute to the promotion of industrial development especially the cosmetic, food, pharmaceutical industry.

\section{Acknowledgements}

E. Baidhe thanks the colleagues of M.Sc. Agricultural Engineering at the Department of Agricultural and Biosystems Engineering, Makerere University for the help and support rendered while conducting this research.

\section{Conflicts of Interest}

The authors declare no conflicts of interest regarding the publication of this paper.

\section{References}

[1] Araújo, R.G., Rodriguez-Jasso, R.M., Ruiz, H.A., Pintado, M.M.E. and Aguilar, C.N. (2018) Avocado By-Products: Nutritional and Functional Properties. Trends in Food Science and Technology, 80, 51-60. https://doi.org/10.1016/j.tifs.2018.07.027

[2] Egbuonu, A.C.C., Opara, C.I., Akachukwu, D. and Onyedikachi, U.B. (2018) Effect of Ethanolic Extract of Avocado Pear (Persea americana) Seed on Normal and Monosodium Glutamate-Compromised Rats' Hepatic Histo-Morphology and Serum Bio-Functional Parameters. Research Journal of Environmental Sciences, 12, 53-62. https://doi.org/10.3923/rjes.2018.53.62

[3] Tremocoldi, M.A., Rosalen, P.L., Franchin, M., Massarioli, A.P., Denny, C., Daiuto, E.R., Paschoal, J.A.R., Melo, P.S. and de Alencar, S.M. (2018) Exploration of Avocado By-Products as Natural Sources of Bioactive Compounds. PLoS ONE, 13, e0192577. https://doi.org/10.1371/journal.pone.0192577

[4] Kiggundu, N., Migliaccio, K.W., Schaffer, B., Li, Y. and Crane, J.H. (2012) Water Savings, Nutrient Leaching, and Fruit Yield in a Young Avocado Orchard as Affected by Irrigation and Nutrient Management. Irrigation Science, 30, 275-286. https://doi.org/10.1007/s00271-011-0280-6

[5] Statista. (2019) Global Avocado Production 2000-2018.

[6] Perea-Moreno, A.-J., Aguilera-Ureña, M.-J. and Manzano-Agugliaro, F. (2016) Fuel Properties of Avocado Stone. Fuel, 186, 358-364.

https://doi.org/10.1016/j.fuel.2016.08.101

[7] FAO. (2019) FAOSTAT Statistical Database of the United Nation Food and Agriculture Organization (FAO) Statistical Division.

[8] Dijkxhoorn, Y., van Galen, M., Barungi, J., Okiira, J., Gema, J. and Janssen, V. (2019) The Vegetables and Fruit Sector in Uganda: Competitiveness, Investment and Trade Options. Wageningen Economic Research, Wageningen, The Netherlands. https://doi.org/10.18174/505785

[9] Sonko, R., Njue, E., Ssebuliba, J. and de Jager, A. (2005) Pro-Poor Horticulture in East Africa and South East Asia. The Horticulture Sector in Uganda.

[10] Adaramola, B., Onigbinde, A. and Shokunbi, O. (2016) Physiochemical Properties and Antioxidant Potential of Persea americana Seed Oil. Chemistry International, 2, 168-175.

[11] Hurtado-Fernández, E., Fernández-Gutiérrez, A. and Carrasco-Pancorbo, A. (2018) Avocado Fruit-Persea americana. Exotic Fruits, 37-48. https://doi.org/10.1016/B978-0-12-803138-4.00001-0 
[12] Duarte, P.F., Chaves, M.A., Borges, C.D. and Mendonça, C.R.B. (2016) Avocado: Characteristics, Health Benefits and Uses. Ciência Rural, 46, 747-754. https://doi.org/10.1590/0103-8478cr20141516

[13] Tibyangye, O. (2017) Sunday Gets Livelihood in Adding Value to Avocado. Daily Monitor.

[14] Markov, S. (2012) Bioprocess Engineering. Applied Science, 240-245.

[15] Erickson, B., Nelson, J.E. and Winters, P. (2012) Perspective on Opportunities in Industrial Biotechnology in Renewable Chemicals. Biotechnology Journal, 7, 176-185. https://doi.org/10.1002/biot.201100069

[16] Satriana, S., Supardan, M.D., Arpi, N. and Wan Mustapha, W.A. (2019) Development of Methods Used in the Extraction of Avocado Oil. European Journal of Lipid Science Technology, 121, Article ID: 1800210. https://doi.org/10.1002/ejlt.201800210

[17] Dreher, M.L. and Davenport, A.J. (2013) Hass Avocado Composition and Potential Health Effects. Critical Reviews in Food Science and Nutrition, 53, 738-750. https://doi.org/10.1080/10408398.2011.556759

[18] Comerford, K.B., Ayoob, K.T., Murray, R.D. and Atkinson, S.A. (2016) The Role of Avocados in Complementary and Transitional Feeding. Nutrients, 8, 316. https://doi.org/10.3390/nu8050316

[19] Aliyu, A.A. (2017) Biogas Potential of Some Selected Kitchen Wastes within Kaduna Metropolis. American Journal of Engineering Research, 6, 53-63.

[20] Owusu, P.A. and Asumadu-Sarkodie, S. (2016) A Review of Renewable Energy Sources, Sustainability Issues and Climate Change Mitigation. Cogent Engineering, 3, 1-14. https://doi.org/10.1080/23311916.2016.1167990

[21] Kenasa, G. and Kena, E. (2019) Optimization of Biogas Production from Avocado Fruit Peel Wastes Co-Digestion with Animal Manure Collected from Juice Vending House in Gimbi Town, Ethiopia. Fermentation Technology, 8, 1-6.

[22] Spence, A., Madrigal, E.B., Patil, R. and Fernández, Y.B. (2019) Evaluation of Anaerobic Digestibility of Energy Crops and Agricultural By-Products. Bioresource Technology Reports, 5, 243-250. https://doi.org/10.1016/j.biteb.2018.11.004

[23] Woldu, A.R., Ashagrie, Y.N. and Tsigie, Y.A. (2015) Bioethanol Production from Avocado Seed Wastes Using Saccharomyces cerevisiae. American Journal of Environment, Energy Power Research, 3, 1-9.

[24] Dagde, K. (2019) Extraction of Vegetable Oil from Avocado Seeds for Production of Biodiesel. Journal of Applied Sciences Environmental Management, 23, 215-221. https://doi.org/10.4314/jasem.v23i2.3

[25] MEMD (2016) Electiricity Connections Policy: Financing and Implementation for Connections, Period: 2018-2027.

[26] Dastan, B., Antwi, D.S., Petra, H. and Vaclav, K. (2017) Firewood and Charcoal Production in Uganda. International Multidisciplinary Scientific GeoConference: SGEM, 17, 521-527. https://doi.org/10.5593/sgem2017H/33/S14.065

[27] Austin, K.F. and Mejia, M.T. (2017) Household Air Pollution as a Silent Killer: Women's Status and Solid Fuel Use in Developing Nations. Population Environment Ecology Research, 39, 1-25. https://doi.org/10.1007/s11111-017-0269-z

[28] Derudi, M., Gelosa, S., Sliepcevich, A., Cattaneo, A., Rota, R., Cavallo, D. and Nano, G. (2012) Emissions of Air Pollutants from Scented Candles Burning in a Test Chamber. Atmospheric Environment, 55, 257-262.

https://doi.org/10.1016/j.atmosenv.2012.03.027 
[29] Deressa, L., Libsu, S., Chavan, R., Manaye, D. and Dabassa, A. (2015) Production of Biogas from Fruit and Vegetable Wastes Mixed with Different Wastes. Environment Ecology Research, 3, 65-71.

[30] Perea-Moreno, M.-A., Samerón-Manzano, E. and Perea-Moreno, A.-J. (2019) Biomass as Renewable Energy: Worldwide Research Trends. Sustainability, 11, 863. https://doi.org/10.3390/su11030863

[31] Chel-Guerrero, L., Barbosa-Martín, E., Martínez-Antonio, A., González-Mondragón, E. and Betancur-Ancona, D. (2016) Some Physicochemical and Rheological Properties of Starch Isolated from Avocado Seeds. International Journal of Biological Macromolecules, 86, 302-308. https://doi.org/10.1016/j.ijbiomac.2016.01.052

[32] Dabas, D., Elias, R.J., Lambert, J.D. and Ziegler, G.R. (2011) A Colored Avocado Seed Extract as a Potential Natural Colorant. Journal of Food Science, 76, C1335-C1341. https://doi.org/10.1111/j.1750-3841.2011.02415.x

[33] Dabas, D., Shegog, R.M., Ziegler, G.R. and Lambert, J.D. (2013) Avocado (Persea americana) Seed as a Source of Bioactive Phytochemicals. Current Pharmaceutical Design, 19, 6133-6140. https://doi.org/10.2174/1381612811319340007

[34] Maryam, K.A. and Santosa. (2016) Utilization Starch of Avocado Seed (Persea americana Mill.) as a Raw Material for Dextrin. Journal of Food Science and Engineering, 6, 32-37. https://doi.org/10.17265/2159-5828/2016.01.005

[35] Nguyen, T.V., Ma, T.-H.N., Nguyen, T.T., Ho, V.-N.K. and Vo, H.T. (2018) Optimization of Maltodextrin Production from Avocado Seed Starch by Response Surface Methodology. AIP Conference Proceedings, No. 1, Article ID: 040004. https://doi.org/10.1063/1.5033404

[36] Silva, I.R.A., Magnani, M., de Albuquerque, F.S.M., Batista, K.S., Aquino, J.d.S. and Queiroga-Neto, V. (2017) Characterization of the Chemical and Structural Properties of Native and Acetylated Starches from Avocado (Persea americana Mill.) Seeds. International Journal of Food Properties, 20, 279-289.

https://doi.org/10.1080/10942912.2017.1295259

[37] Nsubuga, D., Banadda, N. and Kiggundu, N. (2019) Innovations in Value-Addition of Agricultural By-Products in Uganda. Journal of Environmental Protection, 10, 1493-1506. https://doi.org/10.4236/jep.2019.1011089

[38] Raji, I. and Onu, P. (2017) Untapped Wealth Potential in Fruit for Uganda Community. International Journal of Advanced Academic Research, 3, 17-25.

[39] Rachimoellah, H., Resti, D.A., Zibbeni, A. and Susila, I.W. (2009) Production of Biodiesel through Transesterification of Avocado (Persea gratissima) Seed Oil Using Base Catalyst. Jurnal Teknik Mesin, 11, 85-90.

[40] Demshemino, S., Yahaya, M., Nwadike, I. and Okora, L. (2013) Comparative Analysis of Biodiesel and Petroleum Diesel. International journal of Education Research, $1,1-8$.

[41] Deepalakshmi, S., Sivalingam, A., Thirumarimurugan, M., Yasvanthrajan, N. and Sivakumar, P. (2014) In-Situ Transesterification and Process Optimization of Biodiesel from Waste Avocado Seed. Journal of Chemical and Pharmaceutical Sciences (Special Issue), 4, 115-118.

[42] Masturi, M., Cristina, A., Istiana, N., Sunarno, S. and Dwijananti, P. (2017) Ethanol Production from Fermentation of Arum Manis Mango Seeds (Mangifera Indica L.) Using Saccharomyces Crevisiaea. Jurnal Bahan Alam Terbarukan, 6, 56-60. https://doi.org/10.15294/jbat.v6i1.8139

[43] Beschkov, V. (2017) Biogas, Biodiesel and Bioethanol as Multifunctional Renewable Fuels and Raw Materials. In: Jacob-Lopes, E. and Queiroz Zepka, L., Eds., Frontiers 
in Bioenergy and Biofuels, IntechOpen, London, 185-205. https://doi.org/10.5772/65734

[44] Lachenmeier, D. (2008) Safety Evaluation of Topical Applications of Ethanol on the Skin and Inside the Oral Cavity. Journal of Occupational Medicine and Toxicology, 3,1-16. https://doi.org/10.1186/1745-6673-3-26

[45] Sugibayashi, K., Yusuf, E., Todo, H., Dahlizar, S., Sakdiset, P., Arce Jr., F. and See, G.L. (2019) Halal Cosmetics: A Review on Ingredients, Production, and Testing Methods. Cosmetics, 6, 37. https://doi.org/10.3390/cosmetics6030037

[46] Hashim, P. and Mat Hashim, D. (2013) A Review of Cosmetic and Personal Care Products: Halal Perspective and Detection of Ingredient. Pertanika Journals of Science Technology, 21, 281-292.

[47] Bušić, A., Marđetko, N., Kundas, S., Morzak, G., Belskaya, H., Ivančić Šantek, M., Komes, D., Novak, S. and Šantek, B. (2018) Bioethanol Production from Renewable Raw Materials and Its Separation and Purification: A Review. Food Technology Biotechnology, 56, 289-311. https://doi.org/10.17113/ftb.56.03.18.5546

[48] Kampf, G. (2018) Efficacy of Ethanol against Viruses in Hand Disinfection. Journal of Hospital Infection, 98, 331-338. https://doi.org/10.1016/j.jhin.2017.08.025

[49] Raghubanshi, B.R., Sapkota, S., Adhikari, A., Dutta, A., Bhattarai, U. and Bhandari, R. (2017) Use of 90\% Ethanol to Decontaminate Stethoscopes in Resource Limited Settings. Antimicrobial Resistance Infection Control, 6, Article No. 68. https://doi.org/10.1186/s13756-017-0224-x

[50] Wanyama, P., Kiremire, B., Ogwok, P. and Murumu, J. (2011) Indigenous Plants in Uganda as Potential Sources of Textile Dyes. African Journal of Plant Science, 5, 28-39.

[51] Canbolat, Ş., Merdan, N., Dayığlu, H. and Koçak, D. (2015) Investigation of the Dyeability Behavior of Banana Fibers with Natural Dye Extract Obtained from Turmeric Plants. Marmara Journal of Pure and Applied Sciences, 90, 40-44.

[52] Kabir, S.M.F., Chakraborty, S., Hoque, S.M.A. and Mathur, K. (2019) Sustainability Assessment of Cotton-Based Textile Wet Processing. Clean Technology, 1, 232-246. https://doi.org/10.3390/cleantechnol1010016

[53] Bhandari, B. and Rani, A. (2018) Dyeing of Protein Fabrics Exploring Locally Available Weed Plants. Journal of Applied Natural Science, 10, 475-478.

[54] Sagar, N.A., Pareek, S., Sharma, S., Yahia, E.M. and Lobo, M.G. (2018) Fruit and Vegetable Waste: Bioactive Compounds, Their Extraction, and Possible Utilization. Comprehensive Reviews in Food Science Food Safety, 17, 512-531. https://doi.org/10.1111/1541-4337.12330

[55] Manek, R., Builders, P., Kolling, B., Emeje, M. and Kunle, O. (2012) Physicochemical and Binder Properties of Starch Obtained from Cyperus esculentus. AAPS PharmSciTech, 13, 379-388. https://doi.org/10.1208/s12249-012-9761-Z

[56] Builders, P.F. and Arhewoh, M.I. (2016) Pharmaceutical Applications of Native Starch in Conventional Drug Delivery. Starch, 68, 864-873. https://doi.org/10.1002/star.201500337

[57] Tesfaye, T., Gibril, M., Sithole, B., Ramjugernath, D., Chavan, R., Chunilall, V. and Gounden, N. (2018) Valorisation of Avocado Seeds: Extraction and Characterisation of Starch for Textile Applications. Clean Technologies Environmental Policy, 20, 2135-2154. https://doi.org/10.1007/s10098-018-1597-0

[58] Wilkinson, J. and Rocha, R. (2009) Agro-Industry Trends, Patterns and Development Impacts. CABI for FAO UNIDO, Wallingford, UK, 46-91. 
https://doi.org/10.1079/9781845935764.0046

[59] Cruz-Romero, M. and Kerry, J. (2008) Crop-Based Biodegradable Packaging and Its Environmental Implications. CAB Reviews, 3, 1-25. https://doi.org/10.1079/PAVSNNR20083074

[60] Ioannou, I. and Ghoul, M. (2013) Prevention of Enzymatic Browning in Fruit and Vegetables. European Scientific Journal, 9, 310-341.

[61] He, Q. and Luo, Y. (2007) Enzymatic Browning and Its Control in Fresh-Cut Produce. Stewart Postharvest Review, 3, 1-7. https://doi.org/10.2212/spr.2007.6.16

[62] Amado, D.A.V., Helmann, G.A.B., Detoni, A.M., de Carvalh, S.L.C., de Aguiar, C.M., Martin, C.A., Tiuman, T.S. and Cottica, S.M. (2019) Antioxidant and Antibacterial Activity and Preliminary Toxicity Analysis of Four Varieties of Avocado (Persea americana Mill.). Brazilian Journal of Food Technology, 22, 1-11. https://doi.org/10.1590/1981-6723.04418

[63] Fernández-Castañeda, L.A., Arias-Candamil, H., Zapata-Torres, B. and Ardila-Castañeda, M.P. (2018) Evaluation of the Antimicrobial Capacity of Hass Avocado Seed Extract (Persea americana) for Potential Application in the Meat Industry. Dyna, 85, 346-350. https://doi.org/10.15446/dyna.v85n207.72980

[64] Segovia, F.J., Hidalgo, G.I., Villasante, J., Ramis, X. and Almajano, M.P. (2018) Avocado Seed: A Comparative Study of Antioxidant Content and Capacity in Protecting Oil Models from Oxidation. Molecules, 23, 2421.

https://doi.org/10.3390/molecules23102421

[65] Andualem, B. and Gessesse, A. (2013) Production of Microbial Medium from Defatted Brebra (Milletia ferruginea) Seed Flour to Substitute Commercial Peptone Agar. Asian Pacific Journal of Tropical Biomedicine, 3, 790-797. https://doi.org/10.1016/S2221-1691(13)60157-4

[66] Tzintzun-Camacho, O., Sánchez-Segura, L., Minchaca-Acosta, A.Z., Rosales-Colunga, L.M., Hernán-dez-Orihuela, A. and Martínez-Antonio, A. (2016) Development of Bacterial Culture Medium from Avocado Seed Waste. Revista Mexicana de Ingeniería Química, 15, 831-842.

[67] Alkhfaji, Z.A.A.A.A. (2018) Bee Collected Pollen Load (BCPL) as Alternative Culture Media for Bacterial and Yeast Growth. Journal of Pharmaceutical Sciences Research, 10, 830-835.

[68] Youssef, H.H., Hamza, M.A., Fayez, M., Mourad, E.F., Saleh, M.Y., Sarhan, M.S., Suker, R.M., Eltahlawy, A.A., Nemr, R.A. and El-Tahan, M. (2016) Plant-Based Culture Media: Efficiently Support Culturing Rhizobacteria and Correctly Mirror Their In-Situ Diversity. Journal of advanced research, 7, 305-316. https://doi.org/10.1016/j.jare.2015.07.005

[69] University, M. (2015) Annual Report 2015.

[70] National Planning Authority (2013) Uganda Vision 2040.

[71] MEMD (2013) Biomass Energy Strategy (BEST) Uganda.

[72] Price, R. (2017) “Clean” Cooking Energy in Uganda-Technologies, Impacts, and Key Barriers and Enablers to Market Acceleration.

[73] Abatenh, E., Gizaw, B., Tsegaye, Z. and Wassie, M. (2017) Application of Microorganisms in Bioremediation-Review. Journal of Environmental Microbiology, 1, 2-9. https://doi.org/10.17352/ojeb.000007

[74] González-Figueredo, C., Flores-Estrella, R.A. and Rojas-Rejón, O.A. (2018) Fermentation: Metabolism, Kinetic Models, and Bioprocessing. In: Shiomi, N., Ed., Current Topics in Biochemical Engineering, IntechOpen, London. 
https://doi.org/10.5772/intechopen.82195

[75] Purohit, H., Kapley, A., Khardenavis, A., Qureshi, A. and Dafale, N.A. (2016) Insights in Waste Management Bioprocesses Using Genomic Tools. In Advances in applied microbiology, Elsevier, 97, 121-170.

https://doi.org/10.1016/bs.aambs.2016.09.002

[76] Munyambonera, E., Mayanja, M.L., Nampeewo, D. and Adong, A. (2014) Access and Use of Credit in Uganda: Unlocking the Dilemma of Financing Small Holder Farmers. Economic Policy Research Centre (EPRC) Policy Brief No. 25.

[77] Zhou, J., Jiao, H. and Li, J. (2017) Providing Appropriate Technology for Emerging Markets: Case Study on China's Solar Thermal Industry. Sustainability, 9, 178. https://doi.org/10.3390/su9020178 